\title{
Rancang Bangun Aplikasi Presensi Guru Sekolah Menggunakan Sidik Jari Dan Raspberry Pi
}

\author{
Afis Julianto ${ }^{1}$, Danuri ${ }^{2}$, Agus Tedyyana ${ }^{3}$ \\ 1,2,3 Jurusan Teknik Informatika, Politeknik Negeri Bengkalis \\ Politeknik Negeri Bengkalis, Jl. Bathin Alam, Sei Alam, Bengkalis \\ E-mail: '1afispolbeng@gmail.com, 22danuri@polbeng.ac.id, ${ }^{3}$ agustedyyana@polbeng.ac.id
}

\begin{abstract}
Abstrak
Kehadiran guru sangat berpengaruh terhadap proses belajar mengajar di sekolah maka dari itu seorang guru haruslah disiplin dalam melakukan kehadiran setiap harinya. Presensi merupakan salah satu cara untuk mencatat kehadiran guru. Berdasarkan hasil dari observasi dan wawancara di sekolah proses presensi masih dilakukan dengan cara melakukan tanda tangan diatas kertas. Cara ini masih kurang efektif dilakukan karena masih ditemui beberapa kelemahan seperti menitip tanda tangan, hadir terlambat dan lupa tanda tangan. Proses pelaporan presensi ke Disdik Kabupaten Bengkalis juga masih dilakukan dengan cara mengirim hasil rekap dalam bentuk laporan. Maka dibutuhkan aplikasi presensi dengan menggunakan mesin sidik jari untuk memudahkan proses presensi. Data presensi akan dikirim ke dalam sebuah server raspberry pi menggunakan web service SOAP dan disimpan kedalam database MySql. Data presensi juga akan dikirim ke Disdik menggunakan web service REST. Hal ini sangat bermanfaat untuk meminimalisir terjadinya kecurangan dalam melakukan presensi, mudah dalam memonitoring kehadiran dan rekap data presensi guru. Disdik Kabupaten Bengkalis juga lebih mudah dalam memonitoring kehadiran guru karena sistem presensi guru di sekolah sudah terintegrasi dengan sistem yang dimiliki oleh Disdik.
\end{abstract}

Kata kunci: Fingerprint, Presensi, Web Service, Raspberry Pi

\begin{abstract}
The presence of teachers is very influential on the teaching and learning process in schools so a teacher must be disciplined in making attendance every day. Presence is one way of record teacher attendance. Based on the results of observations and interviews in schools the attendance process is still done by doing a signature on paper. This method is still less effective because there are still some weaknesses such as signing autographs, being late and forgetting signatures. The process of reporting attendance to Bengkalis District Education Office is also still done by sending the recap results in the form of reports. Then the presence application is needed by using a fingerprint machine to facilitate the presence process. Presence data will be sent to a raspberry pi server using the SOAP web service and stored in the MySql database. Presence data will also be sent to Disdik using the REST web service. This is handy to minimize the occurrence of fraud in presence, easy to monitor the presence and recap of teacher attendance data. The District Education Office of Bengkalis District is also easier to monitor teacher attendance because the teacher attendance system in schools have been integrated with the system owned by Disdik.
\end{abstract}

Keywords: Fingerprint, Presence, Web Server, Raspberry Pi

\section{Pendahuluan}

Menurut pusat bahasa Departemen Pendidikan Nasional menjelaskan bahwa pendidikan adalah proses pengubahan sikap dan tatalaku seseorang atau kelompok orang dalam usaha mendewasakan manusia melalui upaya pengajaran, pelatihan, dan perbuatan mendidik [1]. Dengan adanya pengubahan tingkah laku tersebut tidak luput dari peran seorang guru selaku tenaga pengajar. Guru menjadi faktor penting dalam dunia pendidikan karena guru yang akan melaksanakan proses pembelajaran, menilai hasil pembelajaran, melakukan pembimbingan dan pelatihan. Maka dari itu seorang guru haruslah sangat disiplin dalam menjalankan kewajibannya 
terutama dalam proses kehadiran. Apabila seorang guru tidak displin dalam menjalankan tugasnya maka proses belajar mengajar tidak akan berjalan secara maksimal.

Presensi merupakan salah satu cara untuk mencatat kehadiran dan merupakan bagian penting dari aktifitas pelaporan data kehadiran yang ada dalam sebuah institusi terutama pendidikan. Sistem yang berjalan saat ini masih menggunakan cara manual yaitu dengan melakukan tanda tangan di lembaran kertas untuk proses presensi. Proses pelaporan presensi ke Dinas Pendidikan Bengkalis juga masih dilakukan dengan mengirim laporan dalam bentuk proposal menggunakan media kertas. Maka dari itu sistem yang terkomputerisasi dengan menggunakan mesin fingerprint sangat dibutuhkan karena mudah dalam penggunaannya yang hanya menggunakan sidik jari. Dengan sistem presensi ini akan mengurangi penggunaan kertas sebagai media presensi dan data hasil presensi akan terkirim ke datasbase dinas pendidikan dengan memanfaatkan web service yang dimiliki Disdik sehingga lebih mudah dalam memonitoring kehadiran guru.

Penelitian yang dilakukan oleh Aris dkk (2015) yang berjudul perancangan sistem absensi guru berbasis web pada SMA Islamic Center Tanggerang menghasilkan sebuah sistem informasi absensi guru mulai dari absensi kehadiran guru sampai menghasilkan sebuah laporan absensi guru [2]. Penelitian juga dilakukan oleh Darmawan dkk (2016) yaitu sistem absensi siswa dan pelaporan berbasis fingerprint dan sms gateway, sistem ini memberikan laporan data absensi siswa setiap matapelajaran kepada wali kelas untuk melakukan evaluasi dan pembinaan terhadap siswa yang kehadirannya di bawah $70 \%$ setiap semesternya. Wali murid dan wali kelas juga mendapat informasi berupa sms gateway apabila siswa tidak hadir di sekolah [3].

Penelitian lainnya pernah dilakukan oleh Dien dan Fitriani (2017) yaitu perancangan monitoring absensi dengan fingerprint berbasis online yang terhubung dengan website [4]. Penelitian lainnya yang dilakukan oleh setiawan 2015 yaitu perancangan sistem absensi siswa menggunakan sidik jari dan sms gateway berbasis cloud computing [5]. Integrasi Fingerprint System dengan Real Time Absensi Dosen Berbasis Web oleh Gat (2018) juga menghasilkan sistem presensi dosen yang terintegasi dengan jadwal kuliah dan dapat di monitoring secara realtime[6]. Dalam proses integrasi data presensi dengan menggunakan web service Soap dan Rest karena memiliki protokol HTTP dan HTTPS untuk melakukan pertukaran data [7]. Teknologi Rest menghasilkan data dengan format JSON [8].

Media penyimpanan data hasil presensi akan disimpan di sebuah server local. Raspberry pi akan digunakan sebagai server local karena mampu digunakan sebagai web server untuk menjalankan aplikasi presensi, database server untuk menyimpan data hasil presensi di mysql server, dan file server untuk menyimpan file dokumen, film, musik dan foto [9]. Raspberry pi juga digunakan untuk mengintegrasikan mesin fingerprint dan aplikasi melalui koneksi LAN.

\section{Metode Penelitian}

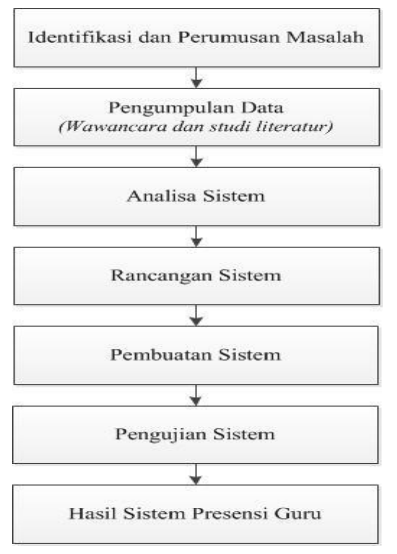

Gambar 1. Metode Penelitian 


\section{a. Identifikasi Masalah}

Identifikasi masalah dilakukan pertama kali untuk mengetahui permasalahan yang terjadi saat ini. Perumusan masalah dilakukan untuk memecahkan masalah dan mencari solusi untuk mengatasi masalah yang sedang terjadi.

\section{b. Pengumpulan Data}

Pengumpulan data dilakukan untuk mendapatkan informasi yang dibutuhkan dalam mencapai tujuan perancangan aplikasi presensi guru. Pengumpulan data dilakukan dengan beberapa tahapan, yaitu :

1. Wawancara

Wawancara dilakukan dibeberapa sekolah yang ada di Kecamatan Bengkalis dan Bantan untuk mendapatkan data dan informasi mengenai sistem presensi yang sedang berjalan saat ini.

2. Studi Literatur

Studi literatur dilakukan dengan cara mencari informasi dan referensi tentang sistem presensi yang sudah pernah diterapkan berupa buku, jurnal online maupun offline dan artikel yang ada diinternet.

\section{c. Analisa Sistem}

Analisa sistem merupakan tahapan yang dibutuhkan dalam melakukan perancangan aplikasi. Pada tahap ini melakukan analisa terhadap data-data yang didapatkan sehingga dapat menganalisa aplikasi yang akan dibangun.

\section{d. Perancangan Sistem}

Perancangan sistem merupakan tahapan dari merancang sebuah aplikasi yang ingin dibangun. Ada beberapa rancangan aplikasi yang digunakan yaitu merancang aplikasi secara umum, perancangan hardware dan perancangan software. Dengan melakukan perancangan aplikasi dapat membuat lebih mudah dalam proses pembuatan aplikasi.

\section{e. Pembuatan Sistem}

Pada tahap ini pembuatan sistem dilakukan dengan melakukan pengkodingan untuk membuat aplikasi berbasis web menggunakan bahasa pemrograman PHP [10], membuat kodingan untuk mengintegrasikan mesin fingerprint dengan aplikasi yang dipasang di raspberry $p i$ dan pembuatan koding untuk melakukan integrasi dengan web service Disdik Kabupaten Bengkalis.

\section{f. Pengujian Sistem}

Pengujian dilakukan dengan tujuan untuk mengetahui apakah sistem yang di bangun sudah berjalan dengan baik atau tidak. Apabila sistem belum berjalan dengan baik maka akan dilakukan perbaikan sampai aplikasi dapat berjalan sesuai dengan yang diharapkan.

\section{g. Hasil}

Hasil atau luaran yang diharapkan dalam perancangan aplikasi presensi guru menggunakan fingerprint dan raspberry pi adalah guru dapat melakukan proses presensi dengan menggunakan mesin fingerprint dan data dapat tersimpan di server raspberry pi kemudian data akan dikirimkan ke database Disdik melalui web service.

\subsection{Perancangan Sistem}

Menurut hasil analisa sistem yang sedang berjalan saat ini, proses yang berlangsung tidak efektif karena terdapat banyak kekurangan. Berikut ini merupakan sistem yang akan dibangun dapat dilihat pada gambar 2 . 


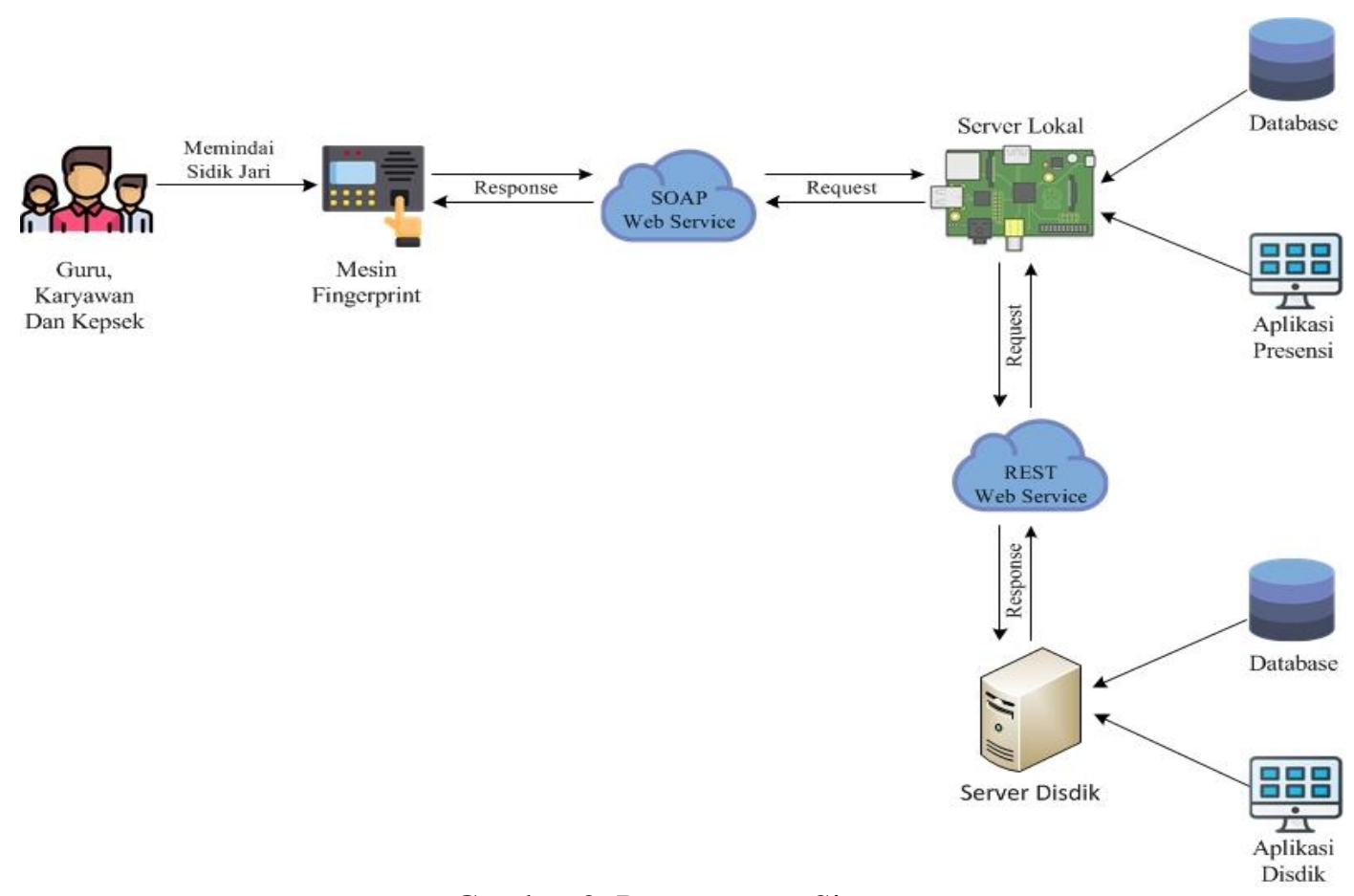

Gambar 2. Perancangan Sistem

\subsection{Use Case Diagram}

Use Case Diagram merupakan gambaran umum tentang sistem [11] yang terdiri dari user dan admin. Berikut ini merupakan Use Case Diagram aplikasi presensi guru dapat di lihat pada gambar 3.

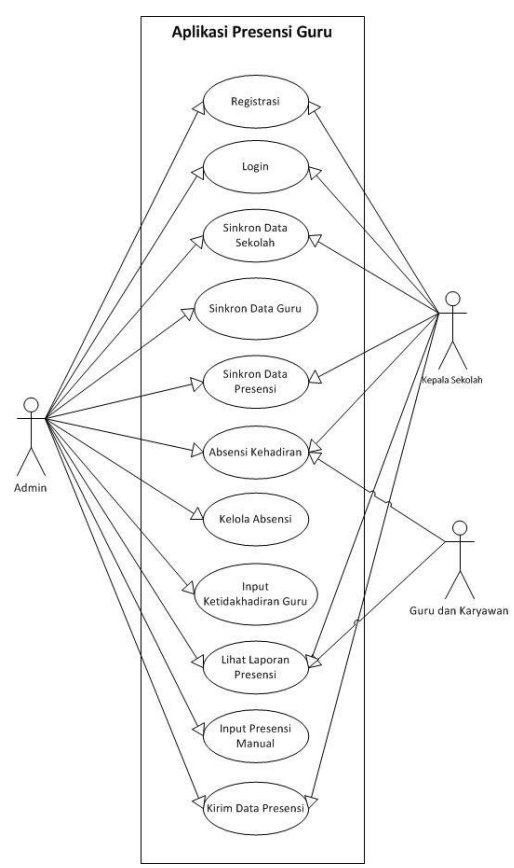

Gambar 3. Use Case Diagram

\subsection{Entity Relationship Diagram (ERD)}

ERD merupakan hubungan antara setiap tabel yang ada pada database aplikasi presensi guru. Relasi antar tabel dapat dilihat pada Gambar 4. 


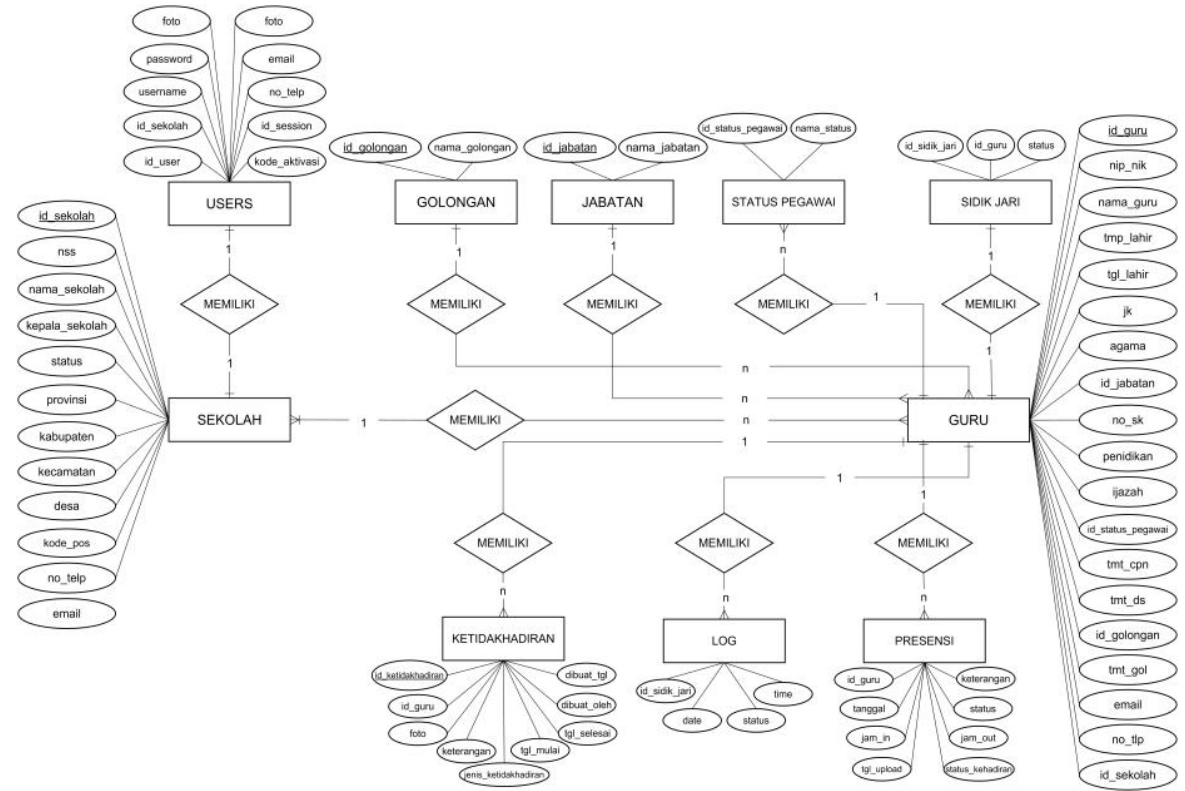

Gambar 4. ERD

\section{Hasil dan Pembahasan}

Penelitian ini menghasilkan aplikasi presensi guru menggunakan sidik jari berbasis website yang terintegrasi dengan web service Dinas Pendidikan Kabupaten Bengkalis. Proses presensi dilakukan dengan menggunakan mesin sidik jari yang terhubung dengan aplikasi presensi sekolah menggunakan jaringan lan. Data hasil presensi akan tersimpan di raspberry pi yang digunakan sebagai database server dan web server aplikasi presensi sekolah. Data hasil presensi akan dikirim ke Dinas Pendidikan Kabupaten Bengkalis melalui web service.

\subsection{Hasil Perancangan Hardware}

Hasil perancangan hardware merupakan hasil dari instalasi mesin fingerprint digunakan untuk mencatat waktu kehadiran guru dan raspberry pi digunakan untuk web server dan database server. Kedua perangkat ini terhubung dengan menggunakan kabel UTP RJ45. Berikut hasil perancangan hardware dapat dilihat pada Gambar 5.
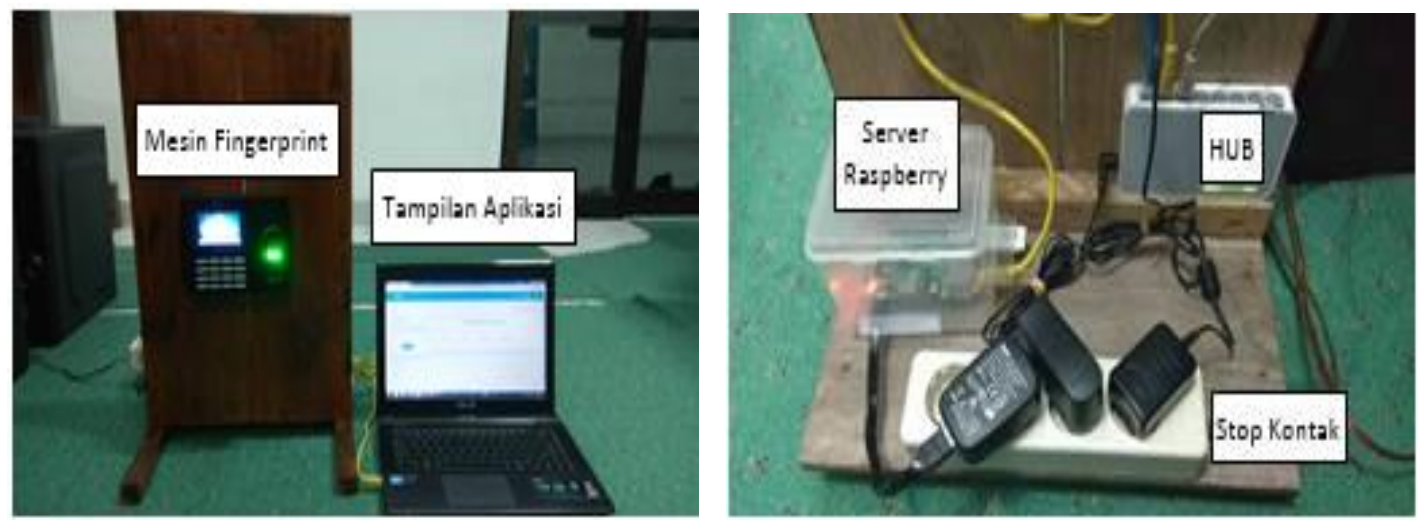

Gambar 5. Hasil Perancangan Server

\subsection{Tampilan Aplikasi}

\section{Tampilan Registrasi}

Tampilan registrasi digunakan untuk memasukkan kode aktivasi sebelum menggunakan aplikasi presensi guru. Kepala sekolah terlebih dahulu melakukan pendaftaran sekolahnya di Disdik Kabupaten Bengkalis untuk mendapatkan kode aktivasi. Berikut tampilan registrasi dapat dilihat pada gambar 6. 


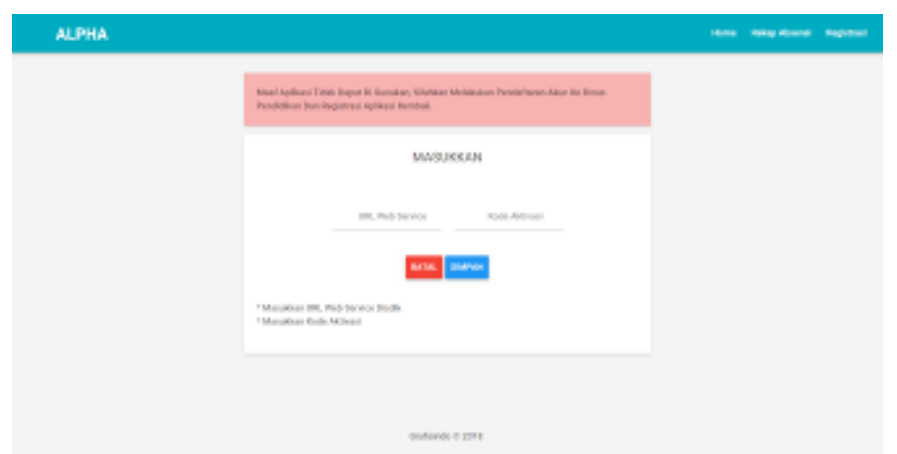

Gambar 6. Tampilan Registrasi

\section{Tampilan Login}

Tampilan login digunakan sebelum membuka Aplikasi Presensi Guru yang akan dilakukan admin dan kepala sekolah. Pada halaman login user akan menginputkan username dan password. Berikut tampilan login dapat dilihat pada gambar 7.

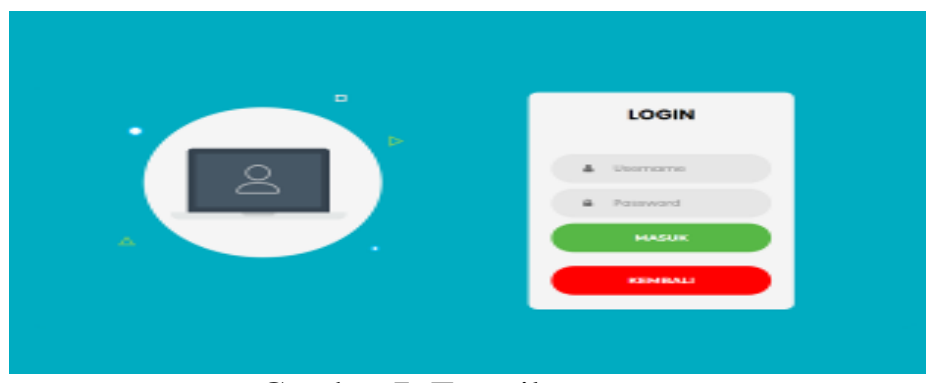

\section{Tampilan Halaman Utama Aplikasi}

\section{Gambar 7. Tampilan Login}

Halaman utama merupakan halaman awal pada aplikasi presensi guru yang menampilkan data hadir, alfa, terlambat, izin, sakit dan dinas. Berikut tampilan halaman utama aplikasi presensi dapat dilihat pada gambar 8 .

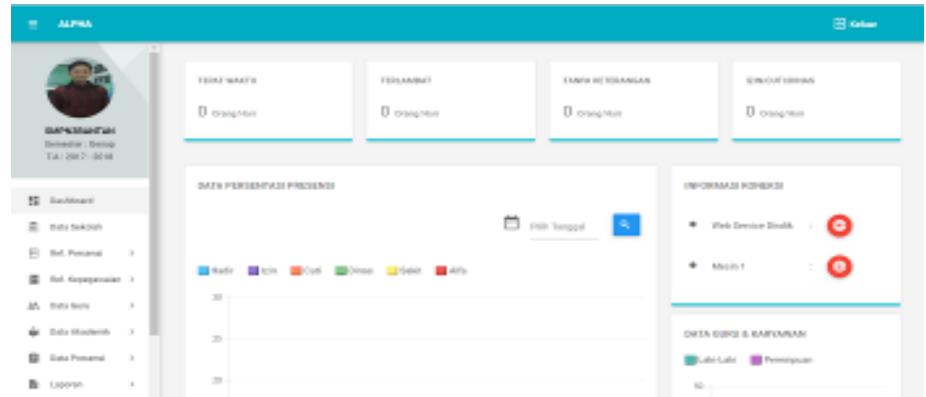

Gambar 8. Tampilan Halaman Utama Aplikasi

\section{Tampilan Sinkron Data Presensi}

Tampilan sinkron data presensi merupakan halaman untuk menampilkan informasi penarikan data dari mesin fingerprint ke database aplikasi presensi. Proses sinkron data presensi dilakukan secara otomatis ketika membuka halaman ini dan otomatis setiap 10 menit. Terdapat beberapa notifikasi yang ada dihalaman ini seperti, notifikasi aktif atau tidaknya mesin dan notifikasi koneksi mesin dan aplikasi. Berikut tampilan sinkron data presensi dapat dilihat pada gambar 9. 


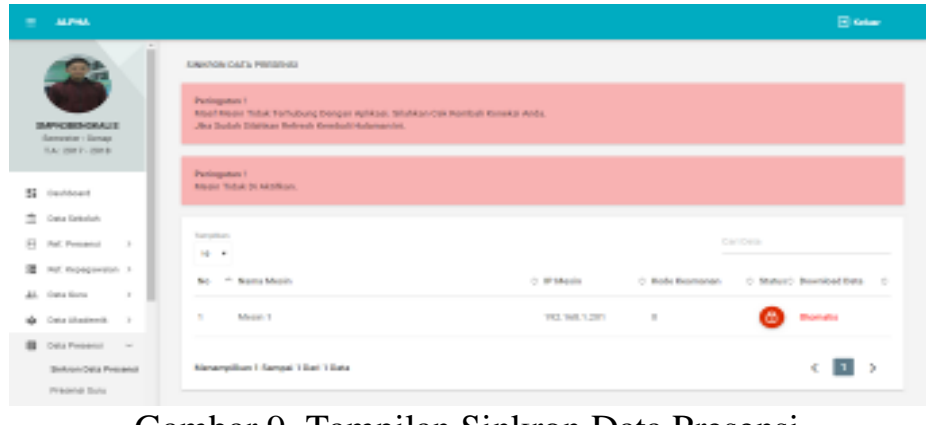

Gambar 9. Tampilan Sinkron Data Presensi

\section{Laporan Presensi Guru}

Laporan presensi guru digunkan untuk menampilkan data rekapitulasi presensi setiap bulan yang dapat dicetak dan di simpan dalam file PDF. Laporan presensi guru dapat dilihat berdasarkan bulan dan tahun. Berikut tampilan laporan presensi guru dapat dilihat pada gambar 10 .

\subsection{Pengujian}

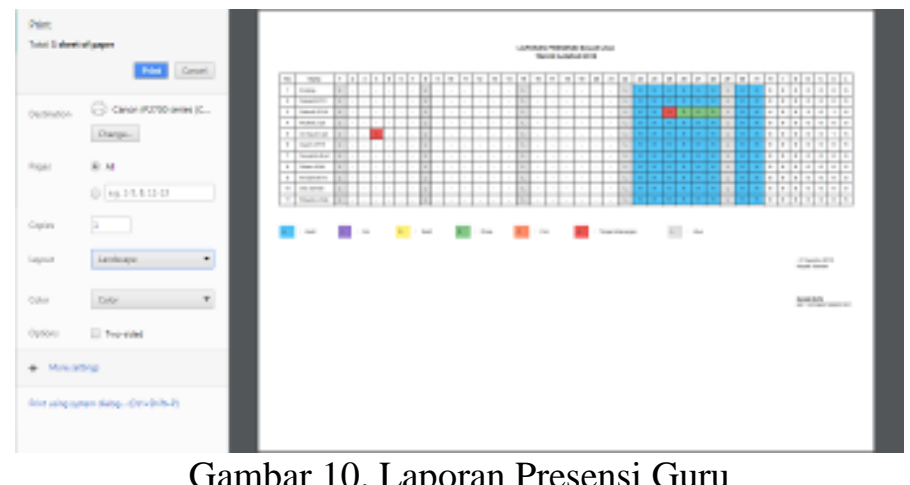

a. Pengujian Integrasi Aplikasi Dengan Mesin Fingerprint

Skenario pengujian dilakukan dengan tujuan apakah sistem dapat berjalan dengan baik atau tidak. Skenario pengujian meliputi integrasi aplikasi dengan mesin fingerprint. Berikut ini hasil pengujian aplikasi dengan mesin fingerprint dapat dilihat pada tabel 1 .

Tabel 1. Hasil Pengujian Integrasi Aplikasi Dengan Mesin Fingerprint

\begin{tabular}{|c|c|c|c|c|c|}
\hline No & Bagian Diuji & $\begin{array}{c}\text { Skenario } \\
\text { Pengujian }\end{array}$ & $\begin{array}{c}\text { Hasil } \\
\text { Diharapkan }\end{array}$ & Hasil Gambar & Hasil \\
\hline 1 & $\begin{array}{lr}\text { Upload data } \\
\text { guru ke } \\
\text { mesin } \\
\text { fingerprint }\end{array}$ & $\begin{array}{l}\text { Menambah } \\
\text { data id sidik } \\
\text { jari dan } \\
\text { melakukan } \\
\text { proses upload } \\
\text { data dari } \\
\text { aplikasi }\end{array}$ & $\begin{array}{l}\text { Mesin akan } \\
\text { menerima id } \\
\text { dan data guru } \\
\text { dari inputan } \\
\text { aplikasi }\end{array}$ & & Berhasil \\
\hline 2 & $\begin{array}{l}\text { Menghapus } \\
\text { data guru }\end{array}$ & \begin{tabular}{ll}
\multicolumn{3}{|c|}{ Menghapus } \\
data id sidik \\
jari & dari \\
aplikasi &
\end{tabular} & $\begin{array}{l}\text { Data guru } \\
\text { dimesin akan } \\
\text { terhapus }\end{array}$ & & Berhasil \\
\hline
\end{tabular}




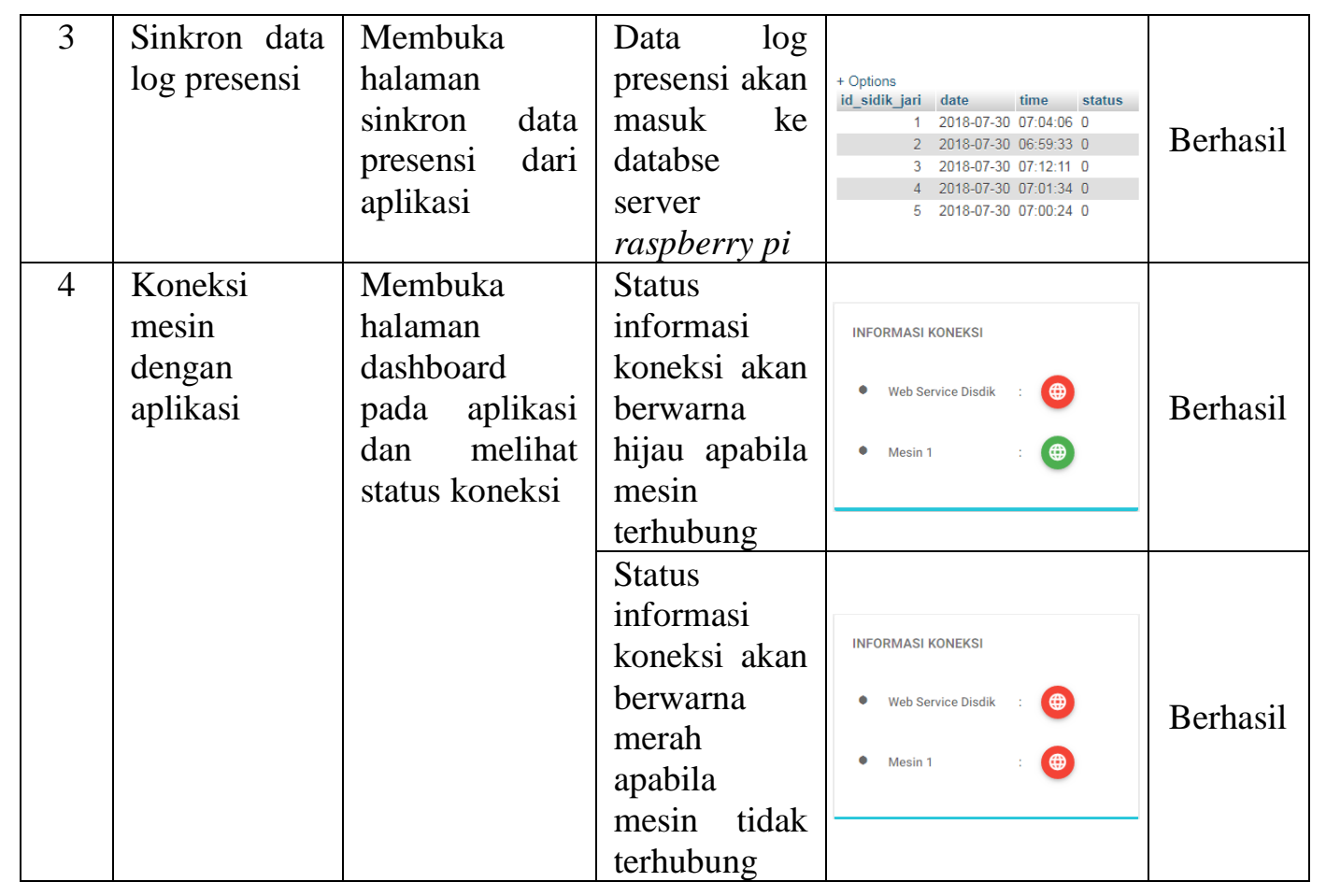

\section{b. Pengujian FungsionalitasAplikasi}

Tabel 2. Hasil Pengujian Fungsionalitas Aplikasi

\begin{tabular}{|c|c|c|c|}
\hline \multirow{2}{*}{ No } & \multirow{2}{*}{ Item Pengujian } & \multicolumn{2}{|c|}{ Hasil } \\
\hline & & Berhasil & Gagal \\
\hline $\mathbf{A}$ & Proses Input Data & & \\
\hline 1 & Registrasi & $\sqrt{ }$ & - \\
\hline 2 & Login & $\sqrt{ }$ & - \\
\hline 3 & Input Data Web Service & $\sqrt{ }$ & - \\
\hline 4 & Input Data Mesin & $\sqrt{ }$ & - \\
\hline 5 & Setting Jadwal Presensi & $\sqrt{ }$ & - \\
\hline 6 & Input Data Sidik Jari & $\sqrt{ }$ & - \\
\hline 7 & Input Data Ketidakhadiran Guru & $\sqrt{ }$ & - \\
\hline 8 & Input Presensi Manual & $\sqrt{ }$ & - \\
\hline 9 & Input Login Kepala Sekolah & $\sqrt{ }$ & - \\
\hline 10 & Edit Status Kehadiran & $\sqrt{ }$ & - \\
\hline B & Proses Sinkron Data & & \\
\hline 1 & Sinkron Data Sekolah & $\sqrt{ }$ & - \\
\hline 2 & Sinkron Data Golongan & $\sqrt{ }$ & - \\
\hline 3 & Sinkron Data Jabatan & $\sqrt{ }$ & - \\
\hline 4 & Sinkron Data Status Pegawai & $\sqrt{ }$ & - \\
\hline 5 & Sinkron Data Guru & $\sqrt{ }$ & - \\
\hline 6 & Sinkron Data Tahun Ajaran & $\sqrt{ }$ & - \\
\hline 7 & Sinkron Data Semester & $\sqrt{ }$ & - \\
\hline 8 & Sinkron Data Kalender Akademik & $\sqrt{ }$ & - \\
\hline 9 & Sinkron Data Presensi Mesin & $\sqrt{ }$ & - \\
\hline C & Proses Output Data & & \\
\hline 1 & Informasi Koneksi Web Service dan Mesin & $\sqrt{ }$ & - \\
\hline 2 & Informasi Jenis Kelamin Guru dan Karyawan & $\sqrt{ }$ & - \\
\hline 3 & Informasi Kehadiran Guru Harian & $\sqrt{ }$ & - \\
\hline
\end{tabular}




\begin{tabular}{|c|l|c|c|}
\hline 4 & Informasi Sekolah & $\sqrt{ }$ & - \\
\hline 5 & Informasi Data Web Service & $\sqrt{ }$ & - \\
\hline 6 & Informasi Data Mesin & $\sqrt{ }$ & - \\
\hline 7 & Informasi Data Jadwal Presensi & $\sqrt{ }$ & - \\
\hline 8 & Informasi Data Golongan & $\sqrt{ }$ & - \\
\hline 9 & Informasi Data Jabatan & $\sqrt{ }$ & - \\
\hline 10 & Informasi Data Status Pegawai & $\sqrt{ }$ & - \\
\hline 11 & Informasi Data Guru & $\sqrt{ }$ & - \\
\hline 12 & Informasi Data Sidik Jari & $\sqrt{ }$ & - \\
\hline 13 & Informasi Tahun Ajaran & $\sqrt{ }$ & - \\
\hline 14 & Informasi Semester & $\sqrt{ }$ & - \\
\hline 15 & Informasi Data Kalender Akademik & $\sqrt{ }$ & - \\
\hline 16 & Informasi Data Ketidakhadiran Guru & $\sqrt{ }$ & - \\
\hline 17 & Informasi Upload Data & $\sqrt{ }$ & - \\
\hline 18 & Informasi Data Presensi Guru & $\sqrt{ }$ & - \\
\hline 19 & Informasi Data User & $\sqrt{ }$ & - \\
\hline 20 & Informasi Registrasi & & - \\
\hline
\end{tabular}

Hasil penelitian dapat diperoleh sebuah aplikasi presensi guru menggunakan sidik jari berbasis website yang terintegrasi dengan web service Dinas Pendidikan Kabupaten Bengkalis. Proses presensi dilakukan dengan menggunakan mesin sidik jari yang terhubung dengan aplikasi presensi sekolah menggunakan jaringan lan. Data hasil presensi berhasil tersimpan di raspberry pi yang digunakan sebagai database server dan web server aplikasi presensi sekolah. Data hasil presensi berhasil dikirim ke Dinas Pendidikan Kabupaten Bengkalis melalui web service.

\section{Kesimpulan}

Kesimpulan yang diperoleh adalah sebagai berikut :

1. Sistem presensi guru ini mampu menginputkan nama guru ke mesin, menarik dan menghapus data log absensi dari mesin melalui web service yang terdapat pada mesin dengan menggunakan arsitektur komunikasi SOAP.

2. Sistem presensi guru ini mampu melakukan sinkron data dan mengirim data presensi melalui web service yang terdapat pada Disdik dengan menggunakan arsitektur komunikasi REST.

3. Sistem presensi guru ini dapat melakukan proses pengolahan data dari log presensi mesin, kalender akademik dan ketidakhadiran guru untuk menentukan status kehadiran guru.

4. Raspberry pi berjalan dengan baik saat digunakan sebagai web server dan database server untuk menampung data presensi guru dan menggunakan daya yang lebih sedikit dibanding dengan menggunakan pc server.

\section{Daftar Pustaka}

[1] Departemen Pendidikan Nasional. 2002. Kamus Besar Bahasa Indonesia, Jakarta: Balai Pustaka.

[2] Aris, Irren, N. F., Rahayu, L. S., dan Rizky, A. P. (2015) "Perancangan Sistem Absensi Guru Berbasis Web Pada SMA Islamic Centre Tanggerang", Prosiding SNIT 2015, 248.

[3] Darmawan, A., Yuliawati, D., Marcella, O., dan Firmandala, R. (2016) Sistem Absensi Dan Pelaporan Berbasis Fingerprint Dan SMS Gateway, Jurnal Sistem Informasi dan Telematika, 7(1), 32-42.

[4] Dien, M.R., dan Fitriani, L. (2017) Perancangan Monitoring Absensi Dengan Fingerprint Berbasis Online, Jurnal Algoritma Sekolah Tinggi Teknologi, 14(1). 
[5] Setiawan, A. B. (2015) Perancangan Sistem Absensi Siswa Menggunakan Sidik Jari Dan SMS Gateway Berbasis Cloud Computing, Jurusan Teknik Informatika Fakultas Teknologi Informasi.

[6] Gat, (2016) Integrasi Fingerprint System Dengan Real Time Absensi Dosen Berbasis Web (Studi Kasus : STMIK Pontianak), Cogito Smart Jurnal, 2(2).

[7] Halili, F., dan Ramadani, E. (2018) Web Services : A Comparison of Soap and Rest Services, Jurnal Modern Applied Science, 12(3).

[8] Arianto, M. A., Munir, S., Khotmah, K. (2016) Analisis Dan Perancangan Representational State Transfer (REST) Web Service Sistem Informasi Akademik STT Terpadu Nurul Fikri Menggunakan Yii Framework, Jurnal Teknologi Terpadu, 2(2).

[9] Abrar, A., Hidayati, Q., dan Pandu, P. (2016) Serve Portable Berbasis raspberry Pi Sebagai Media Pembelajaran Di Politeknik Negeri Balikpapan, Jurnal Sains Terapan, 2(2).

[10] Isa, I.G.T., dan Hertawan, G.P. (2017) Perancangan Aplikasi Koperasi Simpan Pinjam Berbasis Web (Studi Kasus Kopeasi Mitra Setia), Jurnal Ilmiah Ilmu Ekonomi, 5(10).

[11] Herlawati dan Widodo, Menggunakan UML : Informatika Bandung, 2011.

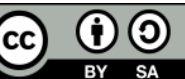

Digital Zone: Jurnal teknologi informasi dan Komunikasi is licensed under a Creative Commons Attribution International (CC BY-SA 4.0) 